\title{
Gambaran Stressor dan Strategi Koping pada Mahasiswa Tahun Pertama Fakultas Keperawatan Universitas Padjadjaran
}

\author{
Intan Febryani Ramadhanti ${ }^{1}$, Nur Oktavia Hidayati ${ }^{2 *}$, Imas Rafiyah ${ }^{3}$ \\ ${ }^{1}$ Mahasiswa Fakultas Keperawatan Universitas Padjadjaran \\ ${ }^{2}$ Dosen Fakultas Keperawatan, Universitas Padjadjaran, Bandung, Indonesia \\ *Email korespondensi : *nuroktaviah@gmail.com
}

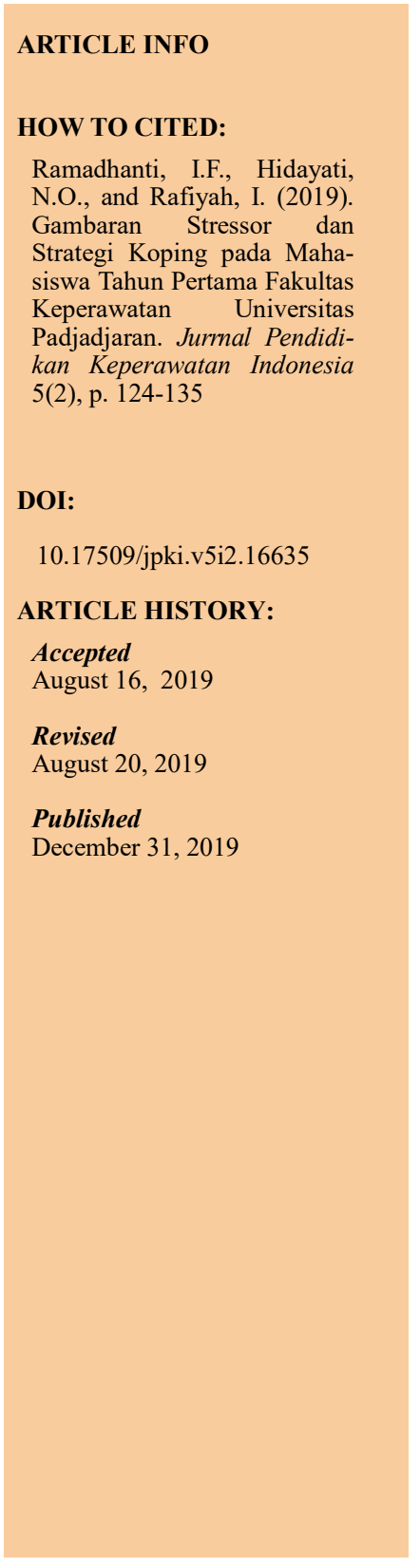

\section{A B S T R A K}

Perubahan yang terjadi dalam masa transisi siswa SMA menjadi mahasiswa cenderung menjadi stressor bagi mahasiswa tahun pertama keperawatan. Stressor tersebut dapat berasal dari internal, keluarga, pendidikan, dan lingkungan sosial. Ketika menghadapi stressor, mahasiswa akan menggunakan strategi koping yang berbeda. Penelitian ini bertujuan untuk menggambarkan stressor dan strategi koping pada mahasiswa tahun pertama Fakultas Keperawatan Universitas Padjadjaran. Penelitian ini merupakan penelitian deskriptif kuantitatif dengan melibatkan 113 orang mahasiswa yang dipilih menggunakan teknik simple random sampling. Data dikumpulkan menggunakan kuesioner stressor dan COPE Inventory yang dianalisis menggunakan analisis deskriptif (frekuensi dan persentase). Hasil penelitian menunjukkan bahwa stressor yang paling banyak dirasakan oleh mahasiswa tahun pertama Fakultas Keperawatan Universitas Padjadjaran berasal dari pendidikan yaitu jadwal kuliah yang berubah-ubah/tidak tepat waktu yang dirasakan $111(98,2 \%)$ mahasiswa. Sedangkan strategi koping yang cenderung digunakan yaitu emotion focused coping sebanyak 65 (57,5\%) mahasiswa. Simpulan dari penelitian ini adalah hampir seluruh mahasiswa merasakan stressor yang berasal dari pendidikan yaitu jadwal kuliah yang berubah-ubah/ tidak tepat waktu, dan sebagian besar mahasiswa cenderung menggunakan strategi koping emotion focused coping. Berdasarkan hasil tersebut, diharapkan ketika ada perubahan jadwal kuliah setiap koordinator mata kuliah mengkonfirmasi kepada mahasiswa beberapa hari sebelumnya, kemudian TPBK dan dosen wali diharapkan untuk selalu melakukan bimbingan pada mahasiswa secara aktif dan berkelanjutan.

Kata kunci: Mahasiswa Keperawatan, Strategi Koping, Stressor, Mahasiswa Tahun Pertama

\section{A B S T R A C T}

Changes that occur in the transition of a senior high school student to college students tend to be a stressor for first-year nursing students. Stressors can come from internal, family, education, and social environment. When experiencing stressors, nursing students will use different coping strategies. This study aims to describe stressors and coping strategies used by the firstyear student of Nursing Faculty, Universitas Padjadjaran. This study is quantitative descriptive research involving 113 students who were selected 
Ramadhanti, I.F., Hidayati, N.O., and Rafiyah, I. | Gambaran Stressor dan Strategi Koping pada Mahasiswa Tahun Pertama...

using a simple random sampling technique. Data were collected using stressors questionnaire and COPE Inventory that analyzed using descriptive analysis (frequency and percentage). The results showed that the stressor most felt by first-year students of Faculty of Nursing Universitas Padjadjaran came from education felt by that is the changing/irregular schedule of lectures perceived 111 (98.2\%) students. While coping strategy that tends to be used is emotion-focused coping as much as 65 (57,5\%) students. This study concludes that almost all students felt the stressor that comes from education that is changing schedule / not on time, and most students tend to use coping strategy emotion-focused coping. Based on the result is expected when there is a change of course schedule every course coordinator in Faculty of Nursing confirm to the student a few days before, then TPBK and guardian lecturer expected always to do guidance to student actively and continuously.

Keywords: Coping Strategies, First-Year Student, Nursing Student, Stressors

\section{PENDAHULUAN}

Mahasiswa keperawatan tahun pertama mengalami masa transisi dari SMA menuju perguruan tinggi. Pada masa tersebut, terdapat berbagai perubahan yang terjadi pada mahasiswa. Diantaranya top-dog phenomenon, yaitu perubahan status dari siswa senior di SMA menjadi mahasiswa junior di perguruan tinggi (Santrock, 2014). Kemudian, terdapat perubahan peralihan tempat tinggal dari rumah ke lingkungan tempat tinggal yang baru (Thurber \& Walton, 2012). Selain itu, terdapat perubahan seperti perbedaan sistem belajar, perilaku individualism, tugas yang menumpuk dengan jangka waktu yang singkat, jarak yang jauh dengan orang tua, kebutuhan untuk menjalin hubungan sosial yang baru dengan teman sekamar, teman atau pacar (Dyson \& Renk, 2006; Tinto, 1987). Adanya perubahan-perubahan tersebut cenderung menjadi stressor tersendiri bagi mahasiswa tahun pertama.

Stressor psikososial pada mahasiswa tahun pertama dapat berasal dari dalam diri individu (internal), keluarga, pendidikan, dan lingkungan sosial (Sarafino, 1994). Adapun, berdasarkan penelitian Shudifat dan Al-Husban (2015) didapatkan hasil bahwa stressor pada mahasiswa keperawatan tahun pertama yaitu peningkatan beban akademik $(89 \%)$, perubahan dalam lingkungan hidup (83\%), perubahan dalam aktivitas sosial $(78 \%)$, perubahan dalam kebiasaan makan (77,5\%), serta perubahan kebiasaan tidur (76\%). Kemudian dalam penelitian Mardiati, Hidayatullah, dan Aminoto (2018) didapatkan hasil bahwa stressor pada mahasiswa keperawatan tahun pertama diantaranya yaitu relasi dengan teman, tugas-tugas kuliah, keuangan, cara dosen dalam penelitian Hardianto (2010) didapatkan hasil bahwa stressor pada mahasiswa keperawatan tahun pertama yang paling banyak dirasakan yaitu pendidikan (74\%), lingkungan sosial (44\%), internal (38)\%, keluarga (28\%).

Berdasarkan survei yang dilakukan oleh American College Health Association (2017) di Amerika didapatkan hasil bahwa stres menjadi salah satu masalah besar yang dihadapi oleh mahasiswa dalam perkuliahan. Sebanyak 33,7\%

dari total 47.821 mahasiswa mengatakan bahwa stres yang dialami menghambat performa akademik mereka. Terdapat beberapa penelitian mengenai tingkat stres pada mahasiswa keperawatan, diantaranya oleh Sharma dan Kaur (2011) di India yang menunjukkan bahwa tingkat stres mahasiswa mayoritas berada pada tingkat sedang yaitu (97 \%), dan tingkat berat sebanyak (3\%). Kemudian Shiferaw dan Nemera (2015) di Ethiopia yang menjelaskan bahwa prevalensi mahasiswa keperawatan yang mengalami stres sebanyak (47,7\%). Di Nigeria oleh Ajibade, Olabisi, Fabiyi, Ajao, dan Ayeni (2016) yang menjelaskan bahwa sebanyak $(50,2 \%)$ mahasiswa mengalami stres ringan, $(33,7 \%)$ stres sedang, dan $(16,1 \%)$ stres berat. Selain itu penelitian lain oleh Mahfouz dan Alsahli (2016) di Saudi Arabia didapatkan hasil bahwa 94,1\% mengalami stres tingkat tinggi dan 5,9\% stres tingkat sedang. Dalam penelitian lain oleh Hasanah (2017) di Indonesia didapatkan hasil bahwa stres tingkat tinggi sebanyak $(62,7 \%)$, stres tingkat sedang $(32,7 \%)$ dan stres tingkat ringan (4,7 \%). Kemudian penelitian di Fakultas Keperawatan Universitas Padjajaran didapatkan hasil bahwa tingkat stres pada mahasiswa tahun pertama yaitu $5,36 \%$ tingkat stres normal, $46,4 \%$ tingkat stres ringan, $41,1 \%$ tingkat stres 
sedang, dan $7,14 \%$ tingkat stres berat (Rachmawati, 2012).

Berdasarkan penelitian yang dilakukan oleh Maulana, Soleha, Saftarina, dan Siagian (2014) diketahui bahwa tingkat stres pada mahasiswa tahun pertama lebih berat dibandingkan dengan mahasiswa tahun kedua, yaitu $(4,3 \%)$ mahasiswa mengalami stres ringan, $(71,7 \%)$ mahasiswa mengalami stres sedang, dan $(23,9 \%)$ mahasiswa mengalami stres berat. Terdapat penelitian lain yang dilakukan oleh Augesti, Lisiswanti, Saputra dan Nisa (2015) yang menunjukkan bahwa tingkat stres pada mahasiswa tahun pertama lebih tinggi dibandingan dengan tingkat stres pada mahasiswa tahun terakhir, yaitu sebanyak (27,5\%) mengalami stres ringan, $(59,2 \%)$ mengalami stres sedang dan $(13,4 \%)$ mengalami stres berat.

Mahasiswa keperawatan tahun pertama mempunyai penilaian terhadap suatu keadaan yang dapat menyebabkan stres yang disebut dengan stress appraisal dan terdiri dari dua tahap yang harus dilalui (Lazarus, 1985 dalam Nasir \& Muhith, 2011). Tahap pertama (primary appraisal) merupakan proses penentuan makna dari suatu peristiwa yang dialami. Kemudian tahap kedua (secondary appraisal) merupakan penilaian mengenai kemampuan pengendalian sumber daya yang dimiliki. Oleh karena itu mahasiswa akan berusaha melakukan suatu upaya sesuai dengan sumber daya yang dimilikinya dalam menghadapi stres. Upaya yang dilakukan baik secara kognitif dan perilaku untuk mengelola tuntutan eksternal dan atau internal yang dinilai membebani atau melewati batas sumber daya yang ada dalam diri individu merupakan strategi koping (Lazarus \& Folkman, 1984).

Terdapat dua jenis strategi koping yang dapat digunakan mahasiswa saat menghadapi masalah, yaitu problem focused coping dan emotion focused coping (Lazarus \& Folkman, 1984). Selain itu, terdapat satu strategi koping oleh Carver, Scheier dan Weintraub (1989) yang dinamakan less useful coping. Mahasiswa yang menggunakan koping yang efektif akan dapat beradaptasi dengan tuntutan dari lingkungan, dan sebaliknya kegagalan dalam menggunakan koping yang efektif beresiko menghasilkan adaptasi yang kurang baik (Lazarus \& Folkman, 1984). Terdapat beberapa dampak negatif dari penggunaan strategi koping yang kurang efektif pada mahasiswa, diantaranya kecemasan, merokok, minum alkohol, depresi dan masalah kesehatan mental lainnya (Pariat, Rynjah, Joplin, \& Kharjana, 2014).

Fakultas Keperawatan Universitas Padjadjaran merupakan pusat pendidikan tinggi keperawatan di Indonesia yang telah terakreditasi A. Seleksi masuk yang digunakan di Fakultas Keperawatan yaitu jalur SNMPTN dan SBMPTN. Selain itu, Fakultas Keperawatan dituntut untuk menghasilkan sumber daya keperawatan yang berkualitas tinggi, sehingga setiap tahunnya selalu dilakukan perbaikan agar sistem pembelajaran menjadi lebih baik. Fakultas Keperawatan menggunakan Kurikulum Berbasis Kompetensi dengan menggunakan metode pembelajaran Student Centered Learning (SCL) melalui lecture, tutorial, laboratorium, self study, serta penugasan terstruktur (FKep UNPAD, 2017

Berdasarkan wawancara terhadap 10 orang mahasiswa tahun pertama (A2017) Fakultas Keperawatan Universitas Padjadjaran, tercatat 8 orang diantaranya merasa tertekan karena sistem belajar di perguruan tinggi yang sangat berbeda dengan SMA, jadwal kuliah yang padat, jadwal ujian yang mendadak, tugas kuliah yang banyak, kelas yang terlalu penuh, kurang bisa bersosialisasi dengan teman baru, pola mengajar dosen yang berbeda dengan guru di SMA, masalah keuangan, sering ingin pulang ke rumah (homesickness), serta belum bisa menyesuaikan diri dengan tempat tinggal yang baru. Adapun gejala yang dirasakan ketika merasa stres yaitu pusing, sakit kepala, merasa lelah, sering mengeluh, dan cenderung lebih emosional. Beberapa cara yang dilakukan untuk menghadapi hal tersebut diantaranya menyendiri, tidur, menonton televisi/film, bermain handphone, makan, jalanjalan, beribadah, bercerita kepada orang tua atau teman yang dianggap dekat, serta menangis.

Selain itu, terdapat tiga orang mahasiswa yang memiliki keinginan untuk melakukan SBMPTN tahun 2018 dan memilih jurusan lain. Hal tersebut dikarenakan dua mahasiswa merasa 
bahwa jurusan keperawatan tidak sesuai dengan passion nya, sedangkan satu orang mahasiswa beralasan karena memiliki indeks prestasi yang kurang memuaskan. Berdasarkan data Indeks Prestasi mahasiswa tahun pertama yang diperoleh dari SBA Fakultas Keperawatan Univesitas Padjadajaran, terdapat sebanyak tujuh mahasiswa memiliki Indeks Prestasi $\leq 2,5$. Kemudian, menurut mahasiswa belum terdapat hal yang dilakukan pihak Fakultas Keperawatan Universitas Padjadjaran dalam membantu mengatasi masalah yang dialami. Berdasarkan fenomena tersebut, peneliti tertarik untuk melakukan penelitian lebih lanjut mengenai gambaran stressor dan strategi koping pada mahasiswa tahun pertama Fakultas Keperawatan Universitas Padjadjaran.

\section{METODE}

Penelitian ini merupakan penelitian deskriptif kuantitatif. Variabel yang digunakan dalam penelitian ini yaitu stressor dan strategi koping mahasiswa tahun pertama (A2017) Fakultas Keperawatan Universitas Padjadjaran. Sub variabel stressor dalam penelitian ini yaitu stressor internal, stressor keluarga, stressor pendidikan, dan stressor lingkungan sosial. Kemudian sub variabel strategi koping yaitu problem focused coping, emotion focused coping, dan less useful coping.

Populasi dalam penelitian ini adalah mahasiswa tahun pertama (A2017) Fakultas Keperawatan Universitas Padjadjaran Jatinangor yang berjumlah 158 mahasiswa berdasarkan data pada tahun 2018. Teknik pengambilan sampel yang digunakan dalam penelitian adalah simple random sampling. Berdasarkan perhitungan dengan menggunakan rumus Slovin didapatkan jumlah sampel dalam penelitian ini adalah sebanyak 113 orang mahasiswa tahun pertama (A2017) Fakultas Keperawatan Universitas Padjadjaran. Penentuan anggota sampel dipilih secara acak dengan melakukan pengundian terhadap seluruh populasi dengan menggunakan kertas yang bertuliskan Nomor Pokok Mahasiswa (NPM).

Instrumen yang digunakan dalam penelitian ini berupa lembar kuesioner yang di dalamnya disertakan angket untuk mengisi karakteristik responden yang terdiri dari jenis kelamin, usia, tempat tinggal, jalur masuk keperawatan, urutan memilih jurusan keperawatan, keinginan memilih jurusan keperawatan, dan uang saku. Untuk mendapatkan gambaran stressor, peneliti menggunakan kuesioner stressor sebanyak 42 item pernyataan yang disusun oleh (Hardianto, 2010), dengan nilai validitas yaitu 0,363 dimana $\mathrm{t}$ hitung $>\mathrm{t}$ table, sehingga seluruh item dinyatakan valid, dan nilai reliabilitas menggunakan alpha cronbach yaitu 0,908 , sehingga instrumen ini dapat dikatakan reliabel untuk digunakan. Sedangkan untuk mendapatkan gambaran strategi koping, peneliti menggunakan instrumen baku COPE Inventory yang disusun oleh Carver, Scheier, dan Weintraub (1989) yang merupakan pengembangan dari alat ukur Lazarus dan Folkman (1984) yaitu Ways of Coping, dan pada penelitian ini peneliti menggunakan instrumen COPE Inventory yang terdiri dari 55 item pernyataan, dimana instrumen ini telah dilakukan uji validitas dengan nilai Goodness of fit Index (GFI), Comparative Fit Index (CFI), Incremental Fit Index (IFI) dengan nilai $>0,9$. Selain itu dilakukan uji signifikansi berdasarkan t-value $>1,96$, dan didaptkan seluruh item telah memnuhi syarat (t-value $>1,96$ ). Seluruh item instrumen ini signifikan, sehingga dapat dikatakan kuesioner ini memiliki validitas yang baik (Sentani, 2016). Sedangkan nilai reliabilitas instrumen ini telah teruji reliabiltasnya dengan nilai alpha cronbach 0,872 .

Data yang diperoleh dianalisis dengan teknik analisis univariat yang bertujuan untuk mendeskripsikan masing-masing variabel yang diteliti sesuai dengan data yang didapat. Untuk mengidentifikasi stressor yang paling banyak dirasakan yaitu dengan cara menjumlahkan skor jawaban responden sesuai item pernyataan kemudian dianalisis melalui distribusi frekuensi, dan disajikan dalam tabel 1.

\section{HASIL}

Penelitian ini mendapatkan hasil bahwa stressor yang paling banyak dirasakan oleh mahasiswa tahun pertama (A2017) Fakultas Keperawatan Universitas Padjadjaran berasal 
Tabel 1 Distribusi Frekuensi Stressor yang Berasal dari Pendidikan, Lingkungan Sosial, Internal, Keluarga $(n=113)$.

\begin{tabular}{|c|c|c|}
\hline Stressor & $\mathbf{f}$ & $\%$ \\
\hline \multicolumn{3}{|l|}{ Pendidikan } \\
\hline Jadwal kuliah berubah-ubah/tidak tepat waktu & 111 & 98,2 \\
\hline Catatan/bahan kuliah dari dosen pada umumnya kurang lengkap & 88 & 77,9 \\
\hline Waktu antara pemberian dan pengumpulan tugas terlalu mendesak & 86 & 76,1 \\
\hline Jadwal kuliah terlalu padat & 85 & 75,2 \\
\hline IPK yang tidak memuaskan & 85 & 75,2 \\
\hline Tugas akademik yang terlalu banyak dan berat & 82 & 72,6 \\
\hline Cara dosen memberikan materi kuliah & 67 & 59,3 \\
\hline Sarana dan prasarana kampus tidak/kurang mendukung & 44 & 38,9 \\
\hline Karyawan akademik kurang bersahabat & 16 & 14,2 \\
\hline \multicolumn{3}{|l|}{ Keluarga } \\
\hline Berpisah dengan orang tua (merantau) & 57 & 50,4 \\
\hline Kondisi ekonomi keluarga yang menurun & 38 & 33,6 \\
\hline Salah satu anggota keluarga sedang sakit & 37 & 32,7 \\
\hline Beban tanggung jawab dalam keluarga terlalu besar & 36 & 31,9 \\
\hline Salah satu anggota keluarga sedang dalam masalah besar & 30 & 26,5 \\
\hline Harapan orang tua tidak sesuai dengan kemampuan & 26 & 23,0 \\
\hline Kematian salah satu anggota keluarga/orang yang dicintai/teman dekat & 26 & 23,0 \\
\hline Konflik dengan salah satu anggota keluarga & 17 & 15,0 \\
\hline Hubungan orang tua (ayah-ibu) tidak harmonis & 17 & 15,0 \\
\hline Orang tua tidak bekerja (PHK) & 15 & 13,3 \\
\hline Kehidupan pribadi terlalu diatur oleh orang tua & 12 & 10,6 \\
\hline Perceraian orang tua & 11 & 9,7 \\
\hline Orang tua tidak mendukung pendidikan yang sedang dijalani & 7 & 6,2 \\
\hline Cara orang tua mendidik terlalu keras & 7 & 6,2 \\
\hline Ikut ayah/ibu tiri & 4 & 3,5 \\
\hline \multicolumn{3}{|l|}{ Lingkungan Sosial } \\
\hline Aktivitas kemahasiswaan yang padat & 77 & 68,1 \\
\hline Canggung berkomunikasi dengan dosen & 73 & 64,6 \\
\hline Canggung berkomunikasi dengan kakak tingkat & 58 & 51,3 \\
\hline Perubahan tempat tinggal (jadi anak kost) & 45 & 39,8 \\
\hline $\begin{array}{l}\text { Lingkungan tempat tinggal/keadaan tempat tinggal tidak mendukung untuk belajar } \\
\text { dengan baik }\end{array}$ & 44 & 38,9 \\
\hline Teman sering mengganggu jam/waktu belajar & 37 & 32,7 \\
\hline Konflik dengan teman & 35 & 31,0 \\
\hline Jarak tempat tinggal dengan kampus terlalu jauh & 34 & 30,1 \\
\hline Kesulitan mendapatkan teman di kampus & 27 & 23,9 \\
\hline \multicolumn{3}{|l|}{ Internal } \\
\hline Tidak dapat mengatur waktu dengan efektif & 91 & 80,5 \\
\hline Kemampuan akademik/intelegensi yang kurang & 76 & 67,3 \\
\hline Tidak ada waktu untuk reskreasi / menyalurkan hobi & 72 & 63,7 \\
\hline Pendidikan yang sedang dijalani tidak sesuai dengan minat dan bakat & 40 & 35,4 \\
\hline Susah mendapatkan teman belajar & 35 & 31,0 \\
\hline Tidak/kurang dihargai teman & 33 & 29,2 \\
\hline Penyakit yang sedang dialami & 24 & 21,2 \\
\hline Cenderung menjadi kritikan / ejekan orang lain & 16 & 14,2 \\
\hline Sedang ada masalah dengan pacar & 11 & 9,7 \\
\hline
\end{tabular}


dari pendidikan, yaitu jadwal kuliah yang berubah-ubah/tidak tepat waktu yang dirasakan oleh $111(98,2) \%$ mahasiswa.

Selain itu, penelitian ini juga mendapatkan hasil bahwa sebagian besar responden yaitu 65 (57.5\%) mahasiswa yang cenderung menggunakan emotion focused coping, sedangkan hampir setengah responden yaitu 48 $(42.5 \%)$ mahasiswa yang cenderung menggunakan problem focused coping. Selain itu didapatkan hasil bahwa tidak seorangpun dari mahasiswa yang cenderung menggunakan less useful coping (lihat tabel 2).

Penelitian menunjukkan bahwa sebagian besar responden yaitu $48(73,85 \%)$ mahasiswa cenderung menggunakan emotion focused coping pada subdimensi turning to religion yang disajikan pada tabel 3. Pada penelitian ini didapatkan hasil bahwa sebanyak 59 (58,4\%) mahasiswa berjenis kelamin perempuan cenderung menggunakan emotion focused coping. sebanyak $6 \quad(50 \%)$ mahasiswa laki-laki cenderung menggunakan problem focused coping. Sebanyak tiga (75\%) mahasiswa yang berusia 20 tahun cenderung menggunakan emotion focused coping. Berdasarkan tempat tinggal, sebanyak $16(51,60 \%)$ mahasiswa yang tinggal dengan orangtua/saudara cenderung menggunakan problem focused coping sedangkan mahasiswa yang tinggal di kost/sewa cenderung menggunakan emotion focused coping yaitu 50 (61,0\%). Sebanyak $9(81,8 \%)$ mahasiswa dengan indeks prestasi 2,00-2,75 dan $55(55,6 \%)$ mahasiswa dengan indeks prestasi 2,76-3,50 cenderung menggunakan emotion focused coping, sedangkan dua $(66,7 \%)$ mahasiswa dengan indeks prestasi 3,51-4,00 cenderung menggunakan problem focused coping.

Berdasarkan jalur masuk, sebanyak 30 $(60 \%)$ mahasiswa SNMPTN maupun 35 $(55,6 \%)$ mahasiswa SBMPTN cenderung menggunakan emotion focused coping. sebanyak $43(56,6 \%)$ mahasiswa yang memilih jurusan keperawatan sebagai pilihan pertama, 18 $(58,1 \%)$ pilihan kedua, maupun empat $(66,7 \%)$

\section{Tabel 2. Distribusi Frekuensi Strategi Koping pada Mahasiswa Tahun Pertama Fakultas Keperawatan Universitas Padjadjaran $(n=113)$}

\begin{tabular}{lll}
\hline Strategi Koping & f & \% \\
\hline Emotion Focused Coping & 65 & 57,5 \\
Problem Focused Coping & 48 & 42,5 \\
\hline
\end{tabular}

Tabel 3. Distribusi Frekuensi Emotion Focused Coping $(n=65)$

\begin{tabular}{lll}
\hline \multicolumn{1}{c}{ Subdimensi } & f & \% \\
\hline Turning to Religion (R) & 48 & 73,85 \\
Positive Reinterpretation and Growth (PRG) & 3 & 4,62 \\
Denial (D) & 2 & 3,08 \\
Seeking Social Support for Emotional Reason (ER) & 2 & 3,08 \\
Humor (H) & 1 & 1,54 \\
R dan PRG & 4 & 6,15 \\
R dan ER & 2 & 3,08 \\
R, PRG, dan A & 2 & 3,08 \\
R, PRG, ER dan A & 1 & 1,54 \\
\hline
\end{tabular}


Ramadhanti, I.F., Hidayati, N.O., and Rafiyah, I. | Gambaran Stressor dan Strategi Koping pada Mahasiswa Tahun Pertama...

Tabel 4. Strategi Koping pada Mahasiswa Tahun Pertama Fakultas Keperawatan Universitas Padjadjaran Berdasarkan Karakteristik Responden $(n=113)$

\begin{tabular}{|c|c|c|c|c|}
\hline \multirow{3}{*}{ Karakteristik Responden } & \multicolumn{4}{|c|}{ Strategi Koping } \\
\hline & \multicolumn{2}{|c|}{ Problem Focused Coping } & \multicolumn{2}{|c|}{ Emotion Focused Coping } \\
\hline & $\mathrm{f}$ & $\%$ & $f$ & $\%$ \\
\hline \multicolumn{5}{|l|}{ Jenis Kelamin } \\
\hline Laki-laki & 6 & 50,0 & 6 & 50,0 \\
\hline Perempuan & 42 & 41,6 & 59 & 58,4 \\
\hline \multicolumn{5}{|l|}{ Usia } \\
\hline 17 tahun & 0 & 0 & 3 & 100 \\
\hline 18 tahun & 21 & 47,7 & 23 & 52,3 \\
\hline 19 tahun & 26 & 41,9 & 36 & 58,1 \\
\hline 20 tahun & 1 & 25 & 3 & 75 \\
\hline \multicolumn{5}{|l|}{ Tempat tinggal selama kuliah } \\
\hline Serumah dengan orang tua/saudara & 16 & 51,6 & 15 & 48,4 \\
\hline Kost/sewa & 32 & 39,0 & 50 & 61,0 \\
\hline \multicolumn{5}{|l|}{ Indeks Prestasi } \\
\hline $2,00-2,75$ & 2 & 18,2 & 9 & 81,8 \\
\hline $2,76-3,50$ & 44 & 44,4 & 55 & 55,6 \\
\hline $3,51-4,00$ & 2 & 66,7 & 1 & 33,3 \\
\hline \multicolumn{5}{|l|}{ Jalur masuk keperawatan } \\
\hline SNMPTN & 20 & 40 & 30 & 60 \\
\hline SBMPTN & 28 & 44,4 & 35 & 55,6 \\
\hline \multicolumn{5}{|l|}{ Pilihan jurusan keperawatan } \\
\hline Pilihan 1 & 33 & 43,4 & 43 & 56,6 \\
\hline Pilihan 2 & 13 & 41,9 & 18 & 58,1 \\
\hline Pilihan 3 & 2 & 33,3 & 4 & 66,7 \\
\hline \multicolumn{5}{|l|}{$\begin{array}{l}\text { Alasan memilih jurusan } \\
\text { keperawatan }\end{array}$} \\
\hline Disuruh oleh orang tua & 16 & 51,6 & 15 & 48,4 \\
\hline $\begin{array}{l}\text { Keinginan sendiri (berdasarkan } \\
\text { minat) }\end{array}$ & 32 & 39,0 & 50 & 61,0 \\
\hline \multicolumn{5}{|l|}{ Jumlah uang saku per-bulan } \\
\hline$<500.000$ & 3 & 37,5 & 5 & 62,5 \\
\hline $500.000-1.000 .000$ & 33 & 45,2 & 40 & 54,8 \\
\hline$>1.000 .000$ & 12 & 37,5 & 20 & 62,5 \\
\hline
\end{tabular}


pada pilihan ketiga, cenderung menggunakan emotion focused coping. Kemudian sebanyak 16 $(51,6 \%)$ mahasiswa yang memilih jurusan keperawatan karena disuruh orang tua cenderung menggunakan problem focused coping, sedangkan sebanyak 50 (61,0\%) karena keinginan sendiri cenderung menggunakan emotion focused coping. Berdasarkan uang saku per-bulan, sebanyak $5(62,5)$ mahasiswa yang memiliki uang saku $<$ Rp500.000,00, $40 \quad(54,8 \%)$ Rp500.000,00-Rp1.000.000,00 maupun 20 $(62,5 \%) \quad>$ Rp1.000.000,00 cenderung menggunakan emotion focused coping. Hasil tersebut dapat dilihat pada tabel 4 .

\section{PEMBAHASAN}

\section{Stressor pada Mahasiswa Tahun Pertama Fakultas Keperawatan Universitas Padjadja- ran}

Stressor yang paling banyak dirasakan berasal dari pendidikan yaitu jadwal kuliah yang berubah-ubah/tidak tepat waktu sebanyak 111 $(98,2 \%)$ yang dirasakan oleh hampir seluruh mahasiswa. Pada dasarnya, penelitian ini mendukung hasil penelitian yang dilakukan oleh Shudifat dan Al-Husban (2015) yang menjelaskan bahwa stressor pada mahasiswa keperawatan tahun pertama yang paling banyak dirasakan yaitu berasal dari beban pendidikan yaitu sebanyak (89\%). Selain itu, mendukung hasil penelitian yang dilakukan oleh Calaguas (2011) yang menjelaskan bahwa stressor terkait jadwal perkuliahan merupakan salah satu dari lima penyebab stres yang sering dialami oleh mahasiswa. Jadwal kuliah yang sering berubah-ubah/ tidak tepat waktu tentu dapat mengganggu jadwal lain yang telah dibuat oleh mahasiswa, sehingga mereka harus berusaha mengatur ulang antara jadwal kuliah, jadwal pengerjaan tugas, serta kegiatan non akademik lainnya.

\section{Strategi Koping pada Mahasiswa Tahun Per- tama Fakultas Keperaeatan Universitas Pad- jadjaran}

Kemudian, pada penelitian ini didapatkan hasil bahwa sebanyak $65(57,5 \%)$ mahasiswa cenderung menggunakan strategi emotion focused coping. Hal ini menunjukkan bahwa sebagian besar responden mengatur respon emosional terhadap masalah atau situasi yang menyebabkan stres. Penggunaan emotion focused coping oleh mahasiswa disebabkan karena sebagian besar mahasiswa tahun pertama menilai bahwa tidak ada yang dapat dilakukan untuk mengubah situasi stres yang dihadapi sehingga mahasiswa mencoba untuk mengatasi aspek emosinya terlebih dahulu sebelum mencoba mengatasi stressor nya. Hasil penelitian ini sejalan dengan penelitian Raudha dan Tahlil (2016) yang menjelaskan bahwa strategi koping dalam mengatasi stres yang paling dominan digunakan oleh mahasiswa keperawatan adalah emotion focused coping yang berjumlah 50 orang responden $(61,7 \%)$. Kemudian hasil penelitian lain yang sejalan yaitu penelitian yang dilakukan oleh Dayfiventy dan Nurhidayah (2012), dan Hirsch (2015) yang menunjukkan bahwa strategi koping yang mayoritas digunakan oleh mahasiswa keperawatan adalah emotion focused coping.

Kecenderuangan strategi koping dominan kedua yang digunakan oleh mahasiswa tahun pertama Fakultas Keperawatan Universitas Padjadjaran yaitu problem focused coping yang cenderung digunakan oleh 48 (42,5\%) mahasiswa. Problem focused coping merupakan usaha mengatasi stres dengan cara mengatur atau mengubah masalah yang dihadapi dan lingkungan sekitarnya yang menyebabkan terjadinya tekanan (Lazarus \& Folkman, 1984). Artinya, hampir sebagian mahasiswa pada penelitian ini menilai sumber atau penyebab dari masalah yang dihadapinya dapat diubah dengan cara mengadapi, mengontrol dan mengelola sumber stres tersebut secara langsung.

Selain itu, pada penelitian ini didapatkan hasil bahwa sebanyak $48(73,85 \%)$ mahasiswa cenderung menggunakan strategi turning to religion yang berarti sebagian besar mahasiswa tahun pertama mencoba mengembalikan permasalahan yang dihadapi pada agama, dengan cara rajin beribadah dan meminta pertolongan pada Tuhan. Mahasiswa yang menggunakan strategi ini mencoba mencari bantuan dan ketenangan dalam menghadapi stressor yang dihadapi seperti berdoa kepada Tuhan agar diberikan 
kelancaran dalam mengerjakan soal ujian.

Berdasarkan jenis kelamin, didapatkan hasil bahwa kecenderungan strategi koping yang digunakan oleh mahasiswa yang berjenis kelamin perempuan adalah emotion focused coping yaitu sebanyak 59 (58,4\%). Kemudian pada mahasiswa yang berjenis kelamin laki-laki kecenderungan strategi koping yang digunakan yaitu $6(50 \%)$ problem focused coping dan enam (50\%) emotion focused coping. Hal ini menunjukan adanya perbedaan strategi koping yang dilakukan oleh mahasiswa berjenis kelamin perempuan dan laki-laki pada mahasiswa tahun pertama Fakultas Keperawatan Universitas Padja djaran.

Hasil penelitian ini sejalan dengan penelitian yang dilakukan oleh oleh Haar dan Morash (1999, dalam Kariv dan Heiman, 2005) yang menjelaskan bahwa perempuan lebih sering melakukan koping untuk mencoba meredakan atau mengatasi emosinya, sedangkan laki-laki sering melakukan koping yang mencoba mengatasi masalahnya. Namun pada penelitian ini, jumlah mahasiswa laki-laki yang menggunakan problem focused coping sebanyak enam (50\%) sama dengan jumlah mahasiswa laki-laki yang menggunakan emotion focused coping yaitu enam (50\%). Peneliti berasumsi bahwa keadaan tersebut disebabkan karena berbagai faktor, salah satunya yaitu sumber daya yang dimiliki oleh mahasiswa laki-laki dalam menentukan strategi koping yang tepat untuk mengatasi stres.

Berdasarkan karakteristik usia, sebanyak tiga (100\%) mahasiswa yang berusia 17 tahun, $23(52,3 \%)$ berusia 18 tahum, $36(58,1 \%)$ berusia 19 tahun, dan $3(75 \%)$ berusia 20 tahun memiliki persamaan yaitu cenderung menggunakan emotion focused coping. Sarafino (1994) menjelaskan bahwa strategi koping yang lebih dilakukan oleh orang dewasa adalah yang berpusat pada pemecahan masalah (problem focused coping), sedangkan pada anak-anak lebih sering menggunakan strategi koping yang berpusat pada emosi (emotion focused coping). Hasil penelitian ini sesuai dengan pernyataan tersebut, karena mahasiswa pada penelitian ini berusia 17-20 tahun dan termasuk ke dalam masa remaja akhir (Desmita, 2007). Masa remaja akhir merupakan masa transisi dari masa anak-anak menuju dewasa awal (Santrock, 2014).

Berdasarkan karakteristik tempat tinggal selama kuliah, sebanyak $16(51,60 \%)$ mahasiswa yang tinggal dengan orang tua/saudara cenderung menggunakan problem focused coping sedangkan mahasiswa yang tinggal sendiri di kost/ sewa cenderung menggunakan emotion focused coping yaitu $50 \quad(61,0 \%)$ mahasiswa. Hasil penelitian ini sejalan dengan penelitian Hestiningrum (2012) yang menjelaskan bahwa mahasiswa yang tinggal di kost lebih sering menggunakan emotion focused coping dari pada mahasiswa yang tinggal di rumah dengan orang tua.

Hasil penelitian berdasarkan karakteristik indeks prestasi, menunjukkan bahwa sebanyak sembilan $(81,8 \%)$ mahasiswa dengan indeks prestasi 2,00-2,75 dan $55(55,6 \%)$ mahasiswa dengan indeks prestasi 2,76-3,50 cenderung menggunakan emotion focused coping, sedangkan dua (66,7\%) mahasiswa dengan indeks prestasi 3,51-4,00 cenderung menggunakan problem focused coping. Hasil penelitian ini berbeda dengan penelitian yang dilakukan oleh Simarmata, Lestari dan Setiawan (2015) yang menjelaskan mahasiswa yang memiliki indeks prestasi 2,00-2,75 cenderung menggunakan problem focused coping yaitu 16 (59,3\%), mahasiswa yang memiliki indeks prestasi 2,76-3,50 dan 3,51-4,00 cenderung menggunakan emotion focused coping yaitu sebanyak $23(76,7 \%)$ dan enam (20,0\%) mahasiswa.

Berdasarkan karakteristik jalur masuk, sebanyak $30(60 \%)$ mahasiswa SNMPTN maupun $35(55,6 \%)$ mahasiswa SBMPTN cenderung menggunakan emotion focused coping. Kemudian sebanyak $43(56,6 \%)$ mahasiswa yang memilih jurusan keperawatan sebagai pilihan pertama, $18(58,1 \%)$ pada pilihan kedua , maupun 4 $(66,7 \%)$ pada pilihan ketiga, cenderung menggunakan emotion focused coping. Peneliti berasumsi bahwa tuntutan bagi mahasiswa yang menggunakan jalur SNMPTN maupun SBMPTN, serta yang memilih jurusan keperawatan pada pilihan pertama, kedua maupun ketiga, dapat dikatakan hampir sama seperti 
tugas yang banyak dengan waktu pengumpulan yang mendesak, tuntutan memiliki nilai IPK yang baik, serta tuntutan dari orang tua untuk lulus tepat waktu.

Berdasarkan karakteristik alasan masuk jurusan keperawatan, didapatkan hasil bahwa sebanyak $16(51,6 \%)$ mahasiswa yang memilih jurusan keperawatan karena disuruh orang tua cenderung menggunakan problem focused coping, sedangkan sebanyak $50 \quad(61,0 \%)$ mahasiswa yang memilih jurusan keperawatan karena keinginan sendiri cenderung menggunakan emotion focused coping. Hasil penelitian ini sejalan dengan penelitian yang dilakukan oleh Intani dan Surjaningrum (2010) yang menjelaskan bahwa mahasiswa yang tidak mendasarkan minat pada pemilihan program studi diperguruan tinggi seperti karena disuruh oleh orang tua cenderung menggunakan problem focused coping dalam menyelesaikan masalah. Hal tersebut dikarenakan mahasiswa cenderung melakukan proses berfikir yang lebih dalam yang menghasilkan insight sebagai dasar dalam menentukan strategi koping.

Penelitian ini didapatkan hasil bahwa berdasarkan uang saku per-bulan, sebanyak lima $(62,5 \%)$ mahasiswa yang memiliki uang saku $<\mathrm{Rp} 500.000,00,40$ (54,8\%) Rp500.000,00 Rp1.000.000,00, maupun $20 \quad(62,5 \%)$ $>$ Rp1.000.000,00 cenderung menggunakan emotion focused coping dalam mengatasi masalah, hal ini tidak sejalan dengan penelitian Mu'tadin (2002) yang berpendapat bahwa materi berupa uang dapat mempengaruhi strategi koping yang digunakan oleh mahasiswa. Selain itu, Stuart (2016) juga berpendapat bahwa sumber dana sangat meningkatkan kemampuan seseorang untuk memilih koping.

\section{SIMPULAN}

Stressor yang paling banyak dirasakan oleh mahasiswa tahun pertama (A2017) Fakultas Keperawatan Universitas Padjadjaran berasal dari pendidikan yaitu jadwal kuliah yang berubah-ubah/tidak tepat waktu yang dirasakan oleh hampir seluruh mahasiswa. Kemudian untuk strategi koping yang digunakan, sebagian besar mahasiswa cenderung menggunakan emotion focused coping, hampir setengah mahasiswa cenderung menggunakan problem focused coping, sedangkan tidak seorangpun mahasiswa yang cenderung menggunakan less useful coping. Dilihat dari subvariabel yang ada, strategi yang paling banyak digunakan dari emotion focused coping yaitu turning to religion yang digunakan oleh sebagian besar mahasiswa.

Dari hasil penelitian, peneliti merekomendasikan kepada pihak Fakultas Keperawatan Universitas Padjadjaran untuk lebih memperhatikan penyebab stres yang dialami mahasiswa khususnya yang terkait dengan pendidikan. Kemudian, ketika ada perubahan jadwal kuliah setiap koordinator mata kuliah mengkonfirmasi kepada mahasiswa beberapa hari sebelumnya. Selanjutnya Tim Pelaksana Bimbingan dan Konseling (TPBK) dan dosen wali diharapkan untuk selalu melakukan bimbingan pada mahasiswa secara aktif dan berkelanjutan. Kemudian, peneliti menyarankan kepada profesi keperawatan khususnya perawat jiwa dan komunitas untuk bekerjasama dengan TPBK dan melakukan pengkajian lebih lanjut tentang keefektifan strategi koping yang digunakan oleh mahasiswa. Selanjutnya, peneliti menyarankan kepada peneliti selanjutnya untuk melakukan penelitian lebih lanjut terkait sumber daya yang dimiliki oleh mahasiswa tahun pertama sebagai bahan dalam memilih strategi koping tertentu yang digunakan, serta jangka waktu dan keefektifan dari strategi koping yang digunakan oleh mahasiswa tahun pertama Fakultas Keperawatan Universitas Padjadjaran. 


\section{REFERENSI}

American College Health Association. (2017). Undergraduate Student Reference Group: Executive Summary Spring.

Augesti, G., Lisiswanti, R., Saputra, O., \& Nisa, K. (2015). Differences in stress level between first year and last year medical students in medical faculty of lampung. J $\mathrm{Ma}$ jority, 4(4), 50-56.

B.L, Ajibade., O.O, Olabisi., B, Fabiyi., O.O, Ajao., \& A.R, Ayeni. (2016). Stress, Types Of Stressors And Coping Strategies Amongst Selected Nursing Schools Students In South-West, Nigeria. European Journal of Biology and Medical Science Research, Vol.4(3), 1-15.

Calaguas, G, M. (2011). College Academic Stress: Difference along Gender Lines. Diunduh 2 Juni 2018 dari http:// www.ifrnd.org

Carver, C. S. . (2013). COPE Inventory. Measurement Instrument Database for the Social Science. Retrieved from www.midss.ie

Dayfiventy, Y., \& Nurhidayah, R. E. (2012). Stressor dan koping mahasiswa pembelajaran kurikulum berbasis kompetensi Fakultas Keperawatan Universitas Sumatera Utara. EJournal USU, 1(1), 6-12.

Desmita. (2007). Psikologi Perkembangan. Bandung: PT Remaja Rosdakarya.

Dyson, R., \& Renk, K. (2006). Freshmen adaptation to University life : depressive symptoms, stress, and coping. Journal of Clinical Psychology, 62, 1231-1244. https:// doi.org/10.1002/jclp.20295

FKep UNPAD. (2017). Pedoman Penyelenggaraan Pendidikan Fakultas Keperawatan Universitas Padjadjaran Tahun Akdemik 2016/2017. Diuduh Januari 10, 2018 dari http://www.unpad.ac.id/wp-content/ uploads/2012/07/BUKU-PEDOMAN-FKEP -2016-2017.pdf

Hardianto. (2010). Gambaran stressor, mekanisme koping dan kemampuan adaptasi pada mahasiswa tahun pertama A 2010 Fakultas Keperawatan Universitas Padjadja- ran. Fakultas Keperawatan Universitas Padjadjaran.

Hasanah, U. (2017). Hubungan antara stres dengan strategi koping mahasiswa tahun pertama akademi keperawatan. Wacana Kesehatan, 1(1), 138-145.

Hestiningrum, E. (2012). Perbedaan Emotional Focused Coping Mahasiswa Kost Dengan Mahasiswa Yang Tinggal Dengan Orang Tua Pada Mahasiswa Jurusan Bimbingan Dan Konseling Fakultas Keguruan dan Ilmu Pendidikan Universitas Ahmad Dahlan Yogyakarta. Psikopedagogia. Vol. 1, No. 2.

Mardiati, A.I., Hidayatullah, F., \& Aminoto,C. (2018). Faktor eksternal tingkat stres mahasiswa keperawatan dalam adaptasi proses pembelajaran. Surakarta: University Research Colloqium.

Hirsch C.D., Barlem E.L.D., Almeida L.K., Tomaschewski-Barlem J.G., Figueira A.B., \& Lunardi V.L (2015). Coping strategies of nursing students for dealing with university stress. Rev Bras Enferm, 68(5), 501-508. https://doi.org/10.1590/00347167.2015680503

Intani, F.S., \& Surjaningrum, E.R. (2010). Coping Strategy pada Mahasiswa Salah Jurusan. Fakultas Psikologi Universitas Airlangga Surabaya. Insan Vol. 12 No. 02.

Kariv, D., \& Heiman, T. (2005). Psychological Testing Principles, Applications, and Issues Sixth Edition. Belmont: Wadsworth.

Lazarus, R.S., \& Folkman, S. (1984). Stress, Appraisal, and Coping. New York: Springer Publishing Company.

Mahfouz, R., \& Alsahli, H. (2016). Perceived Stress and Coping Strategies Among Newly Nurse Students in Clinical Practice. Journal of Educationand Practice, 7(23), 118-128.

Maulana, Z.F., Soleha, T.U., Saftrarina, F., \& Siagian, J.M.C. (2014). Perbedaan Tingkat Stres antara Mahasiswa Tahun Pertama dan Tahun Kedua di Fakultas Kedokteran Universitas Lampung. Majority, 3(4), 154-162.

Mu'tadin, Z. (2002). Strategi Coping. Diakses tanggal 2 Januari 2018 dari http://www.epsikologi.com/remaja/080107.htm 
Nasir, A., \& Muhith, A. (2011). Dasar-Dasar Keperawatan Jiwa. Jakarta: Salemba Medika

Pariat, M. L., Rynjah, M. A., Joplin, M., \& Kharjana, M. G., (2014). Stress Levels of College Students: Interrelationship between Stressors and Coping Strategies. IOSR Journal of Humanities and Social Science, 19(8), 40-45. https://doi.org/10.9790/083719834046

Rachmawati, T. (2012). Gambaran Tingkat Stres pada Mahasiswa Program A 2011 Semester II Fakultas Ilmu Keperawatan Universitas Padjadjaran. Fakultas Keperawatan Universitas Padjadjaran.

Raudha, R., \& Tahlil, T. (2016). Stres dan strategi koping pada mahasiswa keperawatan. Universitas Syiah Kuala Banda Aceh, 1-7.

Santrock, J.W. (2014). Adolescence, 15th edition. New York: McGraw-Hill Education

Sarafino, E.D. (1994). Health Psychology: Biopsycosocial Ineraction, Third Edition. Inggris : John Wiley \& Suns

Sharma, N., \& Kaur, A. (2011). Factors associated with stress among nursing students. Nursing and Midwifery Research Journal, 7 (1), 12-21. https://doi.org/10.9790/195904663338.

Shiferaw, H., Anand, S., \& Nemera, G. (2015). Stress and Coping Strategies Among Generic B.Sc. Nursing Students of Jimma University, South West Ethiopia. International Journal of Recent Advances in Multidisciplinary Research, 0511-0517.
Simarmata, G.E., Lestari, D.R., \& Setiawan, H. (2015). Mekanisme Koping Dengan Prestasi Belajar Mahasiswa Sistem Pembelajaran Blok Angkatan 2013. Program Studi Ilmu Keperawatan Fakultas Kedokteran Universitas Lambung Mangkurat. DK Vol.3 No.1.

Stuart, G.W. (2016). Prinsip dan Praktik Keperawatan Kesehatan Jiwa, Ed.1, terjemahan Budi Anna Keliat dan Jesika Pasaribu. Singapore: Elsevier

Shudifat, R.M., \& Al-Husban, R.Y. (2015). Perceived Sources of Stress Among FirstYear Nursing Students in Jordan. Journal of Psychosocial Nursing and Mental Health Services, 53(6), 37-43.

Sentani, S.R.E. (2016). Gambaran Bentuk Coping Stress Mahasiswa Fakultas Psikologi Universitas Padjadjaran yang Mengalami Stres Akademik. Skripsi. Universitas Padjadjaran

Thurber, C. A., \& Walton, E. A. (2012). Experiences From the Field Homesickness and Adjustment in University Students. Journal of American College Health, 60(5), 1-5. 